\title{
Production and disease resistance of elite black bean lines previously selected using mineral nitrogen fertilization cultivated with natural versus artificial nitrogen supplementation
}

\author{
P.A.S. Dias ${ }^{1}$, P.G.S. Melo ${ }^{1}$, L.C. Melo ${ }^{2}$, T.L.P.O. Souza ${ }^{2}$, L.C. Faria ${ }^{2}$, \\ E.P. B. Ferreira ${ }^{2}$ and H.S. Pereira ${ }^{2}$ \\ ${ }^{1}$ Universidade Federal de Goiás, Goiânia, GO, Brasil \\ ${ }^{2}$ Embrapa Arroz e Feijão, Santo Antônio de Goiás, GO, Brasil \\ Corresponding author: H.S. Pereira \\ E-mail: helton.pereira@embrapa.br
}

Genet. Mol. Res. 19 (2): gmr18491

Received September 25, 2019

Accepted March 31, 2020

Published April 30, 2020

DOI http://dx.doi.org/10.4238/gmr18491

\begin{abstract}
Nitrogen (N) is the most important soil nutrient for common beans; the main sources are mineral $\mathrm{N}$ fertilizers and symbiotic $\mathrm{N}$ fixation (SNF). The common bean (Phaseolus vulgaris) is a $\mathrm{N}$ fixing species, but breeding programs have neglected this fact. We investigates black seeded elite lines grown with mineral $\mathrm{N}$ fertilization or using inoculation with rhizobia to select lines with broad adaptability, high yield stability, and high agronomic performance. Fifteen black seeded common bean elite lines and cultivars, all of them selected under mineral $\mathrm{N}$ fertilization, were evaluated in major bean crop regions in the Brazilian states of Goiás, Paraná and Distrito Federal in different growing seasons and years, totaling 13 environments (combination of location/growing season/year). Two side-by-side experiments were set up in each environment, one exclusively with mineral $\mathrm{N}$ fertilization (total of 80 $\mathrm{kg} \mathrm{ha}^{-1}$ of $\mathrm{N}$ ) and another with Rhizobium inoculation only. The agronomic traits evaluated were seed yield, 100 -seed weight, sieve yield, reaction to anthracnose and angular leaf spot. The nodulation traits evaluated were number of nodules and nodule dry matter, specific weight of nodules and relative nodulation index. The $\mathrm{N}$
\end{abstract}


source significantly affected seed yield, 100 -seed weight and reaction to anthracnose. All lines produced a higher yield and had higher 100seed weight under $\mathrm{N}$ mineral fertilization; but they were more resistant to disease when inoculated with rhizobia. The interaction between lines and $\mathrm{N}$ sources was significant for seed yield, sieve yield, and reaction to anthracnose. However, it did not affect selection of the best lines regardless of $\mathrm{N}$ source. The cultivars BRS FP403 and BRS Esteio are recommended for planting with either of the two $\mathrm{N}$ sources because they were the highest yielding and exhibited high adaptability and stability under both $\mathrm{N}$ supply systems. Selection of superior lines does not appear to depend on the source of $\mathrm{N}$ used during crop development. The lines BRS Campeiro and CNFP 15177 gave the highest nodulation index, indicating that these lines should be used in crosses with high yielding lines to produce lines with high seed yield and high nodulation, reducing possible yield losses in SNF systems compared to those that useonly mineral $\mathrm{N}$ fertilizer.

Key words: Phaseolus vulgaris; SNF; Nodulation; Rhizobium

\section{INTRODUCTION}

Brazil is one of the largest producers and consumers of common beans (Phaseolus vulgaris) (FAO, 2020), with an annual production of approximately 2.7 million tons (Feijão, 2018). Among the several common bean market classes, black beans are the second most consumed by Brazilians, representing around $17 \%$ of national production (Faria et al., 2014).

Recent studies show that the genetic gain in seed yield obtained through plant breeding of black beans is around $1.2 \%$ per year (Faria et al., 2017). Even so, there are many challenges in relation to production of common bean, such as the great diversity of environments in which the crop is grown in Brazil and the high cost of production in systems with high inputs. Thus, breeding programs have been working to improve the sustainability of the crop, such as supplying nitrogen $(\mathrm{N})$ to the plant through symbiotic $\mathrm{N}$ fixation (SNF). This source of $\mathrm{N}$ becomes even more important considering the high cost of mineral $\mathrm{N}$ fertilizer, especially because most bean producers in Brazil are small-scale farmers with little capital for investment (IBGE, 2019). Studies show positive responses of common beans to inoculation with rhizobia in the field (Andraus et al., 2016). However, the level of adoption of this technology is still low and the common bean is considered one of the crops with lowest symbiotic efficiency, with only $39 \%$ of the total $\mathrm{N}$ of the plants coming from SNF (Dwivedi et al., 2015). However, depending on the rhizobia isolate used, the total $\mathrm{N}$ content coming from SNF may reach 75\% (Moreira et al., 2017).

The existence of variability among common bean lines for response to SNF has already been observed in wild germplasm, accessions from germplasm banks (Ferreira et al., 2010; Knupp et al., 2013; Farid and Navabi, 2015), and among breeding lines (Kamfwa et al., 2015; Pereira et al., 2015; Farid et al., 2016, 2017). Variability is also found among common bean genotypes regarding $\mathrm{N}$ absorption efficiency (Fageria et al., 2013; 2015). 
This fact indicates that it is possible to conduct a specific breeding program to develop new common bean lines with greater efficiency for SNF and improved $\mathrm{N}$ absorption as well.

For that reason, all breeding steps must be carried out with the use of Rhizobium inoculation and without the use of $\mathrm{N}$ fertilizer. However, establishment of a specific program takes time and, currently, common bean cultivars specifically developed for this purpose are not yet available to farmers in Brazil. Evaluating and selecting lines that were developed in a growing system with mineral $\mathrm{N}$ fertilization, but have superior performance in a system with Rhizobium inoculation, may permit immediate use of these lines as new cultivars in low $\mathrm{N}$ fields. In addition, since these lines already have various favorable agronomic phenotypes accumulated over years of selection, they can be used in crosses as a source of alleles of agronomic traits (Pereira et al., 2015).

Few studies have evaluated agronomic traits in common bean production systems dependent on SNF, with the exception of a few studies on seed yield and 100 -seed weight (Pelegrin et al., 2009; Fageria et al., 2014; Pereira et al., 2015; Farid et al., 2016; Heilig et al., 2017). Results have been variable, due to differences in genetic variability for $\mathrm{N}$ fixing ability, as well as in the environmental variability that affects the common bean host and the $\mathrm{N}$-fixing bacteria (Hungria and Vargas, 2000; Oliveira et al., 2011; Devi et al., 2013). Information on the influence of inoculation with rhizobia on the occurrence of diseases in common bean is lacking (Huang et al., 2007).

Notable traits related to ability to fix $\mathrm{N}$ are root nodulation, the number and the weight of dry nodules, $\mathrm{N}$ content in plants, shoot dry matter weight, and seed yield (Cardoso et al., 2009, Barros et al., 2013; Fonseca et al., 2013). These traits are not always complementary, due to the complexity of the SNF process. Thus, an ideal common bean line for use in a production system with SNF should have both good nodulation capacity and high seed yield.

The interaction of lines with environments $(G \times E)$ is frequently observed in the common bean crop, especially in Brazil, since it is grown across the country, using varied technology levels, and in different environments (Torga et al., 2016). Under these conditions, it is important that studies focused on SNF be performed in multiple environments, which has not been the case in previous studies.

Based on the importance of multiple environments for traits related to SNF and the long time that lines are bred under synthetic $\mathrm{N}$ fertilizers, the aims of this study were: i) to investigate the effect of $\mathrm{N}$ source (mineral $\mathrm{N}$ fertilization or inoculation with rhizobia) on black seeded elite lines; ii) to select lines with broad adaptability, high yield stability, and high agronomic performance when inoculated with rhizobia alone; iii) and to identify lines with superior expression of nodulation traits.

\section{MATERIAL AND METHODS}

We evaluated 15 black seeded common bean lines, which included five cultivars (BRS Esplendor, BRS Campeiro, BRS Esteio, BRS FP403 and IPR Uirapuru) and 10 elite lines, all of them selected under mineral $\mathrm{N}$ fertilization by Embrapa Arroz e Feijão breeding program. These lines were evaluated in two experiments. In the first experiment, agronomic evaluation of the lines was carried out in multiple environments; and in the second, traits related to nodulation were evaluated in two environments. 
In each environment (combination of location/growing season/year), two experiments were staged side-by-side, both with fertilization with $\mathrm{P}_{2} \mathrm{O}_{5}$ and $\mathrm{K}_{2} \mathrm{O}$ at planting, according to soil analyses. In the first experiment, $\mathrm{N}$ fertilization was applied at sowing (20 $\mathrm{kg} \cdot \mathrm{ha}^{-1}$ of N) and later topdressed with urea, for a total of $80 \mathrm{~kg} \cdot \mathrm{ha}^{-1}$ of N. In the second experiment, no $\mathrm{N}$ fertilizer was applied, but seeds were inoculated with peat inoculant, composed of a 1:1:1 mixture of the strains of Rhizobium tropici (SEMIA 4077 and 4088) and $R$. freirei (SEMIA 4080), registered at the Ministério da Agricultura, Pecuária e Abastecimento (Brazilian Department of Agriculture). The inoculant had a density of $10^{9}$ cells $\mathrm{g}^{-1}$ of peat, and it was applied at a rate of $500 \mathrm{~g}$ of inoculant for $50 \mathrm{~kg}$ of seed. A randomized block experimental design was used in each experiment, with three replicates. Plots consisted of 4 four-meter rows at a spacing of $0.45 \mathrm{~m}$ between rows, with 15 seeds per meter. Crop treatments were carried out as recommended for the common bean crop, except for disease control.

For evaluation of agronomic traits, the lines were tested in five locations, in the states of Goiás (Inhumas, Santo Antônio de Goiás, and Anápolis), Paraná (Ponta Grossa), and in the Distrito Federal (Brasília), in three different growing seasons (rainy, winter, and dry) and in two different years (2011 and 2012). Seed yield, sieve yield, and 100-seed weight were evaluated in 11 environments; reaction to anthracnose (Colletotrichum lindemuthianum) in six environments; and reaction to angular leaf spot (Pseudocercospora griseola) in four environments.

Seed yield, adjusted to $13 \%$ of moisture, was obtained by weighing the seeds harvested from the two center rows of the plot. To obtain sieve yield, a $300 \mathrm{~g}$ sample removed from the plot was sieved through a $4.25 \mathrm{~mm}$ mesh (sieve No. 11). The seeds retained in the sieve were weighed and the sieve yield in percentage was estimated. A random sample of the seeds retained in the sieve was collected and this sample was used to obtain 100-seed weight, expressed in grams. Reaction to anthracnose and angular leaf spot was evaluated using a scoring scale ranging from 1 to 9, where score 1 represents absence of disease and score 9 represents $100 \%$ of plants with symptoms (Melo, 2009).

For evaluation of the nodulation traits, the common bean lines were tested in the 2013 rainy crop season and 2014 winter crop season in Santo Antônio de Goiás, GO, with inoculation of rhizobia and fertilization with $\mathrm{N}$ fertilizer, as described above. For evaluations of nodulation, three plants were collected from one of the rows of each plot in the R6 phenological stage (anthesis). The main stems of those plants were cut off to $1.0 \mathrm{~cm}$ from the soil and the root system was carefully removed from the soil, avoiding losses of roots and nodules. The roots were washed over a sieve in running water. After that, the nodules on the roots were dried in the shade for $24 \mathrm{~h}$. After this period, the nodules were detached and counted, thus determining the number of nodules (NN) per sample. The nodules from each sample were placed in paper envelopes, dried in a forced air circulation laboratory oven for $36 \mathrm{~h}$ at $72^{\circ} \mathrm{C}$, and then weighed for determination of nodule dry matter (NDM). The specific weight of nodules (SWN), which represents the size of the nodule, was obtained by dividing the NDM by the NN. The values of NN, NDM, and SWN were transformed to a scale of 0.0 to 10.0 . The maximum score 10.0 was attributed to the highest value within the data set and the others were obtained by the simple rule of three. After that, the scaled data were used to calculate the relative nodulation index (RNI) for each line, adapted from Ferreira et al. (2010), according to the following estimator: 


$$
\mathrm{RNI}=\frac{(N N * 0.4)+(N D M * 0.8)+(S W N * 1.8)}{3}
$$

Individual and joint analyses of variance were carried out considering the environments (location/growing season/year) by $\mathrm{N}$ source. Finally, joint analysis of variance was carried out considering all the experiments (combinations of location/growing season/year/ $\mathrm{N}$ source). The effects of lines, environments, and $\mathrm{N}$ sources were considered fixed. Homogeneity of the variances was checked by the 7:1 ratio of the mean square residual, as proposed by Pimentel-Gomes (2009). In situations in which the ratio between the higher and lower mean square residual was greater than seven, adjustments of the degrees of freedom of the mean error and of the line by environment interaction were made (Cochran, 1954).

The mean values for all traits were clustered by the Scott-Knott method at $10 \%$ probability. According to Zimmermann (2004), this procedure is recommended when small differences are expected among the treatments, as in the case of experiments with elite lines. For seed yield, a coincidence index was calculated among the lines classified as having greater yield using the two $\mathrm{N}$ sources in each environment, considering selection of the $30 \%$ best (five lines). The relationships between the seed yield of each line under inoculation and under $\mathrm{N}$ fertilization (RYIN), in percentage, were estimated as following:

$$
\operatorname{RYIN}_{\mathrm{i}}=\left(\frac{Y I E L D_{\text {inoc }}}{Y_{\text {IIELL }}}\right) * 100
$$

in which: YIELD ${ }_{\text {inoc }}$ is the seed yield with inoculation of line $i$; and YIELD ${ }_{\text {nitro }}$ is the seed yield with $\mathrm{N}$ fertilization of line $i$.

Spearman correlations were estimated for all traits, using the mean values with inoculation and with $\mathrm{N}$ fertilization in each environment and also based on the mean values of combined analysis, to identify if there was interaction between the lines and the $\mathrm{N}$ source and if there was predominance of simple or complex interactions. Spearman correlations which ranged from 0.00 to 0.40 and were significant indicated predominantly complex interaction; from 0.41 to 0.60 and significant indicated that the interactions of the simple and complex type were not significantly different; and from 0.61 to 1.00 and significant indicated predominantly simple interactions. The coincidence among the $30 \%$ best lines based on overall classification was also estimated.

Analyses of adaptability and stability for seed yield were also performed, consisting of a general analysis, considering the experiments with $\mathrm{N}$ fertilizer and the inoculated treatments together, and two other analyses separating the experiments in a system with $\mathrm{N}$ fertilization and with inoculation with rhizobia. To do so, the method of Nunes et al. (2005) was used. Initially, the means of the lines in the diverse environments were standardized, per plot, obtaining $\mathrm{Z}_{\mathrm{ij}}$. As the standardized variable $z_{\mathrm{ij}}$ assumed positive and negative values, a constant $\mathrm{k}$ was added $(\mathrm{k}=3.0)$ to the values of $z_{\mathrm{ij}}$ so that all values would be positive. The mean of the values of $z_{\mathrm{ij}}$ for a determined line is its measure of adaptability, and the coefficient of variation of the $z_{\mathrm{ij}}\left(C V_{z i}\right)$ for each line is the measure of its stability. 
The lines that showed $C V_{Z i} \leq 20 \%$ were considered as very stable, that showed $20 \%<C V_{Z i}$ $\leq 25 \%$ as stable, and that showed $C V_{Z i}>25 \%$ as unstable.

\section{RESULTS}

The effects of common bean lines, environments, and $\mathrm{N}$ sources for seed yield were highly significant (Table 1). Genetic variability for seed yield among black seeded common bean lines under $\mathrm{N}$ fertilization and/or inoculation with rhizobia has been observed by other authors (Brito et al., 2010; Torga et al., 2013). The influence of the $\mathrm{N}$ source can be observed comparing the mean values of seed yield under $\mathrm{N}$ fertilization $\left(2,567 \mathrm{~kg} \cdot \mathrm{ha}^{-1}\right)$ and under SNF (2,396 kg.ha ${ }^{-1}$ ) (Table 2). Brito et al. (2008) also obtained higher seed yield when there was $\mathrm{N}$ fertilization in black bean lines. Nevertheless, even with a lower mean, it is important to emphasize that inoculation with rhizobia is a practice with lower cost and environmental impact than application of $\mathrm{N}$ fertilizer. This results in greater profitability for the producer and sustainability of production systems (Pelegrin et al., 2009).

The interaction between common bean lines and $\mathrm{N}$ sources was significant, indicating variation in the performance of the lines according to changes in the $\mathrm{N}$ source (Table 1). The Spearman correlation $\left(\mathrm{r}_{\mathrm{s}}\right)$ estimates support the findings of analysis of variance, since in $73 \%$ of the environments evaluated the $r_{s}$ values were not significant, indicating a predominance of complex interactions. However, the overall correlation $\left(\mathrm{r}_{\mathrm{s}}=\right.$ $0.54^{*}$, Table 1) was intermediate, showing a balanced importance of the simple and complex interactions, and, consequently, moderate effects in the ranking of the lines.

Table 1. Summary of joint analyses of variance for seed yield $\left(\mathrm{kg} \mathrm{ha}^{-1}\right)$, sieve yield (\%), 100 -seed weight (g), reaction to anthracnose (scores from 1 to 9), and reaction to angular leaf spot (scores from 1 to 9) of black seeded common bean lines.

\begin{tabular}{|c|c|c|c|c|c|c|c|c|c|c|c|c|c|c|c|}
\hline \multirow{2}{*}{ Source of variation } & \multicolumn{3}{|c|}{ Seed yield } & \multicolumn{3}{|c|}{ Sieve yield } & \multicolumn{3}{|c|}{ 100-seed weight } & \multicolumn{2}{|c|}{ Anthracnose } & \multicolumn{4}{|c|}{ Angular leaf spot } \\
\hline & $\mathbf{D F}^{1}$ & $\mathbf{M S}^{2}$ & P-value & DF & MS & P-value & DF & MS & P-value & DF & MS & P-value & $\overline{D F}$ & MS & P-value \\
\hline Blocks/Experiment" & 44 & 461,641 & 0.000 & 44 & 79.9 & 0.005 & 44 & 1.0 & 0.163 & 12 & 3.03 & 0.210 & 8 & 5.35 & 0.000 \\
\hline Lines (L) & 14 & $2,217,873$ & 0.000 & 14 & 2621.4 & 0.000 & 14 & 231.7 & 0.000 & 14 & 70.87 & 0.000 & 14 & 12.72 & 0.000 \\
\hline Environments (E) & 10 & $101,065,473$ & 0.000 & 10 & 25934.1 & 0.000 & 10 & 381.2 & 0.000 & 5 & 30.38 & 0.000 & 3 & 41.85 & 0.000 \\
\hline N Sources (S) & 1 & $7,282,533$ & 0.000 & 1 & 0.4 & 0.924 & 1 & 33.8 & 0.000 & 1 & 9.34 & 0.045 & 1 & 2.60 & 0.092 \\
\hline $\mathrm{L} \times \mathrm{E}$ & 140 & 400,990 & 0.000 & 140 & 290.6 & 0.000 & 140 & 3.7 & 0.000 & 70 & 7.09 & 0.000 & 42 & 1.63 & 0.007 \\
\hline $\mathrm{L} \times \mathrm{S}$ & 14 & $4,003,303$ & 0.004 & 14 & 151.0 & 0.000 & 14 & 1.2 & 0.098 & 14 & 4.97 & 0.011 & 14 & 0.87 & 0.489 \\
\hline $\mathrm{E} \times \mathrm{S}$ & 10 & $1,981,992$ & 0.000 & 10 & 266.9 & 0.000 & 10 & 17.3 & 0.000 & 5 & 6.62 & 0.011 & 3 & 8.79 & 0.000 \\
\hline$L \times E \times S$ & 140 & 253,703 & 0.001 & 140 & 99.8 & 0.000 & 140 & 1.3 & 0.000 & 70 & 2.49 & 0.210 & 42 & 0.73 & 0.780 \\
\hline Residue & 616 & 170,954 & - & 616 & 47.5 & - & 616 & 0.8 & - & 168 & 2.29 & - & 112 & 0.90 & - \\
\hline Total & 989 & & & 989 & & & 989 & & & 359 & & & 239 & & \\
\hline Mean $^{3}$ & 2,482 & & & 71.1 & & & 22.0 & & & 3.3 & & & 4.7 & & \\
\hline $\mathrm{C}^{4}(\%)$ & 60 & & & 80 & & & 80 & & & 80 & & & 80 & & \\
\hline $\mathrm{CV}^{5}(\%)$ & 16.7 & & & 9.7 & & & 4.1 & & & 46.2 & & & 20.2 & & \\
\hline $\mathrm{r}_{\mathrm{s}}^{6}$ & $0.54^{\prime \prime}$ & & & $0.91^{* *}$ & & & $0.98^{* 1}$ & & & $0.78^{* 7}$ & & & $0.81^{\text {"n }}$ & & \\
\hline
\end{tabular}

The coincidence in selection of the $30 \%$ best performing common bean lines was high $(\mathrm{C}=60 \%)$, indicating that three among the five highest yielding lines would coincide in selection (BRS FP403, BRS Esteio, and BRS Esplendor) in comparing the two systems of $\mathrm{N}$ supply. Evaluating coincidence per environment, in $64 \%$ of them, coincidence was greater than or equal to $60 \%$. For selection with intensity of $10 \%$ (two superior lines), 
coincidence would be maximum (100\%), and the cultivars BRS Esteio and BRS FP403 would be selected using either of the two N sources.

Table 2. Seed yield (BSY - Kg.ha ${ }^{-1}$ ), parameter of adaptability (Zi) and stability (CVi) of black seeded common bean lines under nitrogen fertilization and inoculation with rhizobia, and relationship between seed yield with inoculation and with nitrogen fertilization (RYIN - \%).

\begin{tabular}{|c|c|c|c|c|c|c|c|c|c|c|}
\hline \multirow{2}{*}{ Line } & \multicolumn{3}{|c|}{-Both N sources } & \multicolumn{3}{|c|}{ Nitrogen fertilization } & \multicolumn{3}{|c|}{ Rhizobia inoculation } & \multirow{2}{*}{ RYIN } \\
\hline & BSY & $\mathrm{Zi}$ & $\mathrm{CVi}$ & BSY & $\mathbf{Z i}$ & $\mathrm{CVi}$ & BSY & $\mathbf{Z i}$ & CVi & \\
\hline BRS FP403 & $2,851 \mathrm{~A}$ & 4.05 & 21.9 & $3,041 \mathrm{Aa}$ & 4.14 & 31.4 & $2,662 \mathrm{Ab}$ & 3.97 & 20.6 & 87.5 \\
\hline BRS Esteio & $2,833 \mathrm{~A}$ & 3.91 & 21.3 & $2,931 \mathrm{Aa}$ & 3.82 & 28.8 & $2,734 \mathrm{Ab}$ & 3.99 & 22.1 & 93.3 \\
\hline BRS Esplendor & $2,639 \mathrm{~B}$ & 3.47 & 26.3 & $2,742 \mathrm{Ba}$ & 3.54 & 38.0 & $2,536 \mathrm{Bb}$ & 3.41 & 26.4 & 92.5 \\
\hline BRS Campeiro & $2,611 \mathrm{~B}$ & 3.29 & 30.7 & $2,789 \mathrm{Ba}$ & 3.49 & 41.8 & $2,432 \mathrm{Cb}$ & 3.10 & 32.0 & 87.2 \\
\hline CNFP 15171 & $2,475 \mathrm{C}$ & 3.11 & 27.9 & $2,437 \mathrm{Ca}$ & 2.68 & 43.0 & $2,512 \mathrm{Ba}$ & 3.55 & 22.7 & 103.1 \\
\hline IPR Uirapuru & $2,471 \mathrm{C}$ & 2.92 & 23.1 & $2,546 \mathrm{Ca}$ & 2.87 & 40.3 & $2,397 \mathrm{Ca}$ & 2.97 & 20.9 & 94.2 \\
\hline CNFP 15178 & $2,450 \mathrm{C}$ & 2.95 & 22.3 & $2,547 \mathrm{Ca}$ & 3.00 & 43.2 & $2,352 \mathrm{Cb}$ & 2.91 & 14.1 & 92.3 \\
\hline CNFP 15174 & $2,432 \mathrm{C}$ & 2.94 & 31.7 & $2,388 \mathrm{Da}$ & 2.67 & 56.5 & $2,477 \mathrm{Ba}$ & 3.21 & 27.3 & 103.7 \\
\hline CNFP 15194 & $2,429 \mathrm{C}$ & 2.76 & 33.2 & $2,545 \mathrm{Ca}$ & 2.84 & 53.3 & $2,312 \mathrm{Cb}$ & 2.68 & 33.0 & 90.9 \\
\hline CNFP 15193 & $2,418 \mathrm{C}$ & 2.77 & 27.2 & $2,501 \mathrm{Ca}$ & 2.83 & 28.7 & $2,335 \mathrm{Ca}$ & 2.71 & 35.1 & 93.4 \\
\hline CNFP 15207 & $2,394 \mathrm{C}$ & 2.79 & 36.4 & $2,489 \mathrm{Ca}$ & 2.82 & 49.2 & $2,298 \mathrm{Cb}$ & 2.75 & 42.4 & 92.3 \\
\hline CNFP 15198 & $2,394 \mathrm{C}$ & 2.75 & 23.1 & $2,539 \mathrm{Ca}$ & 2.91 & 35.7 & $2,250 \mathrm{Db}$ & 2.60 & 22.2 & 88.6 \\
\hline CNFP 15208 & $2,336 \mathrm{C}$ & 2.53 & 32.3 & $2,507 \mathrm{Ca}$ & 2.84 & 49.9 & $2,165 \mathrm{Db}$ & 2.23 & 27.0 & 86.3 \\
\hline CNFP 15177 & $2,324 \mathrm{C}$ & 2.70 & 36.2 & $2,265 \mathrm{Da}$ & 2.37 & 70.4 & $2,382 \mathrm{Ca}$ & 3.02 & 30.2 & 105.2 \\
\hline CNFP 15188 & $2,170 \mathrm{D}$ & 2.05 & 34.1 & $2,245 \mathrm{Da}$ & 2.19 & 57.4 & $2,095 \mathrm{Da}$ & 1.91 & 37.7 & 93.3 \\
\hline Mean & 2,482 & - & - & $2,567 \mathrm{a}$ & - & - & $2,396 \mathrm{~b}$ & - & - & 93.6 \\
\hline
\end{tabular}

Even with interaction between common bean lines and $\mathrm{N}$ sources being significant and indicating greater importance of complex interaction by the correlation estimates, the high coincidence indicates that selection of the best performing lines would still be the same using either of the two $\mathrm{N}$ sources. This result indicates that the complex interaction that was detected occurs due to change in the ranking of the median to lower yielding lines. Thus, the superior common bean lines for seed yield developed under $\mathrm{N}$ fertilization can be recommended for systems inoculated with Rhizobium.

In general, the black seeded lines were higher yielding when $\mathrm{N}$ fertilizer was applied (Table 2), suggesting the importance of the $\mathrm{N}$ source used in the selection process and the influence of the management condition to which the lines were subjected over the years of selection. Farid et al. (2017) found similar results. The black seeded cultivars BRS FP403 and BRS Esteio were superior for seed yield, both in overall classification and in the two $\mathrm{N}$ sources separately. Comparing the relationship between seed yield under inoculation and with $\mathrm{N}$ fertilization of these two cultivars, the cultivar BRS Esteio stands out, with RYIN of $93.3 \%$, indicating that this cultivar can be grown under either of the two systems of $\mathrm{N}$ supply. The cultivar BRS FP403 had an RYIN of $87.5 \%$, one of the lowest relationships, but even so, showing a higher yield than most of the lines, with either of the $\mathrm{N}$ sources. The lines CNFP 15177, CNFP 15174, and CNFP 15171 presented excellent RYINs (above 100\%), but were not the highest yielding, which explains the lack of recommendation of them as cultivars. However, these lines can be used in crosses with very high yielding parents, such as BRS Esteio and BRS FP403, and the resulting populations can be grown and advanced in environments under inoculation, aiming to obtaining high yielding lines with high RYIN too. 
The fact of there is significant interaction between lines and $\mathrm{N}$ sources $(\mathrm{L} \times \mathrm{S})$ justifies the use of analysis of adaptability (Zi) and stability (CVi) (Table 2). The cultivars BRS FP403 and BRS Esteio, in addition to being high yielding, were the most adapted in overall classification and considering both $\mathrm{N}$ sources. These cultivars were also considered stable $(\mathrm{CVi}$ from $20.1 \%$ to $25 \%$ ) in overall classification and under inoculation. However, they were unstable under $\mathrm{N}$ fertilization $(\mathrm{CVi}<25 \%)$. Regarding to the $\mathrm{L} \times \mathrm{S}$ interaction, these cultivars had high seed yield performance, wide adaptability, and stability considering both $\mathrm{N}$ sources (Table 2).

For the traits related to commercial quality of the seeds, differences were observed among the lines and among the environments for sieve yield and 100-seed weight (100SW), and between N sources only for 100SW (Table 1). Other authors (Pereira et al., 2012; Fageria et al., 2014) have reported genetic variability for these traits. In general, greater 100SW was obtained when there was $\mathrm{N}$ fertilization (Table 3). The lines shown significant $\mathrm{L}$ x S interaction only for seed yield (Table 1). There are only few studies on the interaction between genotypes and environments for common bean seed quality traits and, in general, they report experiments that involve lines from different market classes (Pereira et al., 2012; Fageria et al., 2014). For most of these studies, the G $\mathrm{x}$ E interaction was detected, showing the importance of evaluating the common bean lines in multiple environments.

Most of the estimates of Spearman correlation (86\%) by environment ranged from intermediate to high and were significant $\left(r_{s}>0.40^{*}\right)$ for seed yield and $100 \mathrm{SW}$. The general $\mathrm{r}_{\mathrm{s}}$ were high and significant for seed yield $\left(0.91^{* *}\right)$ and for 100SW $\left(0.98^{* *}\right)$ (Table 1). Coincidences of $80 \%$ were obtained for both traits, i.e., four of the five best lines would be selected with either of the $\mathrm{N}$ sources. Thus, even with the significant interaction between lines and $\mathrm{N}$ sources for seed yield, the effect was small for the purpose of selecting the best common bean lines. The same occurs based on the means of the lines in the two $\mathrm{N}$ systems, since the lines BRS Esteio and CNFP 15188 stood out in the overall mean and also in the two N sources, with seed yield above $80 \%$ (Table 3 ). For $100 \mathrm{SW}$, the cultivar BRS FP403 had the highest overall value $(25.8 \mathrm{~g})$ and the cultivar BRS Campeiro was in the second group of mean values.

Table 3. Evaluation of sieve yield (\%), 100-seed weight (g), reaction to anthracnose (scores from 1 absence of disease - to $9-100 \%$ of plants symptoms), and reaction to angular leaf spot (scores from 1 to 9) of black seeded common bean lines under nitrogen fertilization (Nitro), inoculation with rhizobia (Inoc), and mean of Nitro and Inoc (Mean).

\begin{tabular}{|c|c|c|c|c|c|c|c|c|c|c|c|c|c|c|c|c|c|c|c|c|c|c|c|c|}
\hline \multirow{3}{*}{$\begin{array}{l}\text { Line } \\
\text { BRS FP403 }\end{array}$} & \multicolumn{6}{|c|}{ Sieve yield } & \multicolumn{6}{|c|}{ 100-seed weight } & \multicolumn{6}{|c|}{ Anthracnose } & \multicolumn{6}{|c|}{ Angular leaf spot } \\
\hline & \multicolumn{2}{|c|}{ Mean } & \multicolumn{2}{|l|}{ Nitro } & \multicolumn{2}{|l|}{ Inoc } & \multicolumn{2}{|c|}{ Mean } & \multicolumn{2}{|c|}{ Nitro } & \multicolumn{2}{|l|}{ Inoc } & \multicolumn{2}{|c|}{ Mean } & \multicolumn{2}{|c|}{ Nitro } & \multicolumn{2}{|l|}{ Inoc } & \multicolumn{2}{|c|}{ Mean } & \multicolumn{2}{|c|}{ Nitro } & \multicolumn{2}{|l|}{ Inoc } \\
\hline & 77.6 & $\mathrm{~B}$ & 75.5 & $\mathrm{Bb}$ & 79.6 & $\mathrm{Aa}$ & 25.8 & $\overline{\mathrm{A}}$ & 26.0 & $\mathrm{Aa}$ & 25.5 & $\mathrm{Ab}$ & 4.8 & $\mathrm{C}$ & 5.2 & $\mathrm{Da}$ & 4.5 & $\mathrm{Ca}$ & 4.6 & $\mathrm{~B}$ & 4.1 & $\mathrm{Aa}$ & 5.0 & $\mathrm{Bb}$ \\
\hline BRS Esteio & 80.3 & $\mathrm{~A}$ & 80.4 & $\mathrm{Aa}$ & 80.1 & $\mathrm{Aa}$ & 22.2 & $\mathrm{~F}$ & 22.5 & $\mathrm{Ea}$ & 21.9 & $\mathrm{~Eb}$ & 1.5 & A & 1.1 & $\mathrm{Aa}$ & 1.8 & $\mathrm{Aa}$ & 4.3 & $\mathrm{~B}$ & 3.9 & Aa & 4.6 & $\mathrm{Ba}$ \\
\hline BRS Esplendor & 64.0 & $\mathrm{G}$ & 66.3 & $\mathrm{Ca}$ & 61.6 & $\mathrm{Db}$ & 19.1 & I & 19.3 & Ia & 19.0 & $\mathrm{Ha}$ & 1.9 & A & 2.3 & $\mathrm{Ba}$ & 1.5 & $\mathrm{Aa}$ & 3.8 & $\mathrm{~A}$ & 3.5 & Aa & 4.1 & $\mathrm{Aa}$ \\
\hline BRS Campeiro & 78.4 & B & 77.3 & $\mathrm{Aa}$ & 79.5 & $\mathrm{Aa}$ & 24.2 & $\mathrm{~B}$ & 24.2 & $\mathrm{Ba}$ & 24.3 & $\mathrm{Ba}$ & 3.6 & B & 4.1 & $\mathrm{Ca}$ & 3.1 & $\mathrm{Ba}$ & 5.9 & $\mathrm{D}$ & 5.8 & $\mathrm{Ca}$ & 6.0 & $\mathrm{Ca}$ \\
\hline CNFP 15171 & 63.1 & $\mathrm{G}$ & 62.0 & $\mathrm{Da}$ & 64.2 & $\mathrm{Ca}$ & 19.3 & I & 19.7 & $\mathrm{Ha}$ & 18.9 & $\mathrm{Hb}$ & 5.7 & $\mathrm{D}$ & 5.6 & $\mathrm{Da}$ & 5.8 & $\mathrm{Da}$ & 3.3 & $\mathrm{~A}$ & 3.5 & Aa & 3.1 & $\mathrm{Aa}$ \\
\hline IPR Uirapuru & 75.2 & $\mathrm{C}$ & 73.2 & $\mathrm{Bb}$ & 77.2 & $\mathrm{Aa}$ & 22.1 & $\mathrm{~F}$ & 22.2 & $\mathrm{Ea}$ & 22.0 & $\mathrm{Ea}$ & 3.6 & $\mathrm{~B}$ & 4.3 & $\mathrm{Cb}$ & 2.9 & $\mathrm{Ba}$ & 4.4 & $\mathrm{~B}$ & 4.1 & Aa & 4.8 & $\mathrm{Ba}$ \\
\hline CNFP 15178 & 68.9 & $\mathrm{E}$ & 67.7 & $\mathrm{Ca}$ & 70.1 & $\mathrm{Ba}$ & 20.4 & $\mathrm{H}$ & 20.5 & $\mathrm{Ga}$ & 20.3 & $\mathrm{Ga}$ & 4.6 & $\mathrm{C}$ & 5.8 & $\mathrm{Db}$ & 3.5 & $\mathrm{Ba}$ & 3.9 & A & 4.1 & Aa & 3.8 & $\mathrm{Aa}$ \\
\hline CNFP 15174 & 66.1 & $\mathrm{~F}$ & 66.7 & $\mathrm{Ca}$ & 65.4 & $\mathrm{Ca}$ & 20.1 & $\mathrm{H}$ & 20.2 & $\mathrm{Ga}$ & 19.9 & $\mathrm{Ga}$ & 5.7 & $\mathrm{D}$ & 5.5 & $\mathrm{Da}$ & 5.9 & $\mathrm{Da}$ & 3.9 & A & 3.9 & Aa & 4.0 & $\mathrm{Aa}$ \\
\hline CNFP 15194 & 67.1 & $\mathrm{~F}$ & 68.7 & $\mathrm{Ca}$ & 65.6 & $\mathrm{Cb}$ & 22.8 & $\mathrm{D}$ & 22.9 & $\mathrm{Da}$ & 22.7 & $\mathrm{Ca}$ & 1.9 & A & 1.8 & $\mathrm{Aa}$ & 1.9 & $\mathrm{Aa}$ & 5.9 & $\mathrm{D}$ & 6.1 & $\mathrm{Ca}$ & 5.8 & $\mathrm{Ca}$ \\
\hline CNFP 15193 & 71.5 & $\mathrm{D}$ & 74.2 & $\mathrm{Ba}$ & 68.9 & $\mathrm{Bb}$ & 23.3 & $\mathrm{C}$ & 23.6 & $\mathrm{Ca}$ & 22.9 & $\mathrm{Cb}$ & 1.8 & A & 1.3 & $\mathrm{Aa}$ & 2.2 & $\mathrm{Aa}$ & 6.4 & $\mathrm{D}$ & 6.1 & $\mathrm{Ca}$ & 6.6 & $\mathrm{Ca}$ \\
\hline CNFP 15207 & 71.6 & $\mathrm{D}$ & 71.7 & $\mathrm{Ba}$ & 71.5 & $\mathrm{Ba}$ & 22.8 & D & 23.3 & $\mathrm{Ca}$ & 22.4 & $\mathrm{Db}$ & 2.0 & A & 1.8 & $\mathrm{Aa}$ & 2.1 & $\mathrm{Aa}$ & 5.0 & $\mathrm{C}$ & 4.9 & $\mathrm{Ba}$ & 5.1 & $\mathrm{Ba}$ \\
\hline CNFP 15198 & 60.5 & $\mathrm{H}$ & 62.0 & $\mathrm{Da}$ & 59.1 & $\mathrm{Da}$ & 21.3 & G & 21.5 & $\mathrm{Fa}$ & 21.1 & $\mathrm{Fa}$ & 3.8 & $\mathrm{~B}$ & 3.3 & $\mathrm{Ba}$ & 4.3 & $\mathrm{Ca}$ & 4.6 & B & 4.4 & Aa & 4.9 & $\mathrm{Ba}$ \\
\hline CNFP 15208 & 72.6 & $\mathrm{D}$ & 73.3 & $\mathrm{Ba}$ & 71.9 & $\mathrm{Ba}$ & 23.2 & $\mathrm{C}$ & 23.5 & $\mathrm{Ca}$ & 22.8 & $\mathrm{Cb}$ & 1.2 & A & 1.4 & $\mathrm{Aa}$ & 1.0 & $\mathrm{Aa}$ & 5.2 & $\mathrm{C}$ & 5.0 & $\mathrm{Ba}$ & 5.4 & $\mathrm{Ba}$ \\
\hline CNFP 15177 & 69.7 & $\mathrm{E}$ & 68.4 & $\mathrm{Ca}$ & 71.0 & $\mathrm{Ba}$ & 20.3 & $\mathrm{H}$ & 20.4 & $\mathrm{Ga}$ & 20.2 & $\mathrm{Ga}$ & 5.7 & D & 6.2 & $\mathrm{Da}$ & 5.3 & $\mathrm{Da}$ & 3.9 & A & 3.9 & $\mathrm{Aa}$ & 3.9 & $\mathrm{Aa}$ \\
\hline CNFP 15188 & 80.2 & $\mathrm{~A}$ & 79.6 & $\mathrm{Aa}$ & 80.8 & $\mathrm{Aa}$ & 22.5 & $\mathrm{E}$ & 22.6 & $\mathrm{Ea}$ & 22.5 & Da & 1.4 & $\mathrm{~A}$ & 1.8 & $\mathrm{Aa}$ & 1.0 & $\mathrm{Aa}$ & 5.2 & $\mathrm{C}$ & 5.5 & $\mathrm{Ca}$ & 4.9 & $\mathrm{Ba}$ \\
\hline Mean & 71.1 & & 71.1 & $\mathrm{a}$ & 71.1 & $\mathrm{a}$ & 22.0 & & 22.1 & $\mathrm{a}$ & 21.8 & $\bar{b}$ & 3.3 & & 3.4 & $\mathrm{~b}$ & 3.1 & $\bar{a}$ & 4.7 & & 4.6 & $a$ & 4.8 & $\mathrm{a}$ \\
\hline
\end{tabular}

Mean values followed by the same lowercase letters in the table line and uppercase letters in the same column (Scott-Knott method, $\alpha=$ $10 \%$ ) do not differ statistically. 
Resistance to diseases is another important objective of common bean breeding programs. For reaction to anthracnose and to angular leaf spot, significant effects of lines and of environments were observed, as reported in other studies (Pereira et al., 2012; 2018). There was a significant effect of the $\mathrm{N}$ source in the reaction to anthracnose, with a positive effect from inoculation with rhizobia (Table 3 ). The interaction between lines and $\mathrm{N}$ sources was also significant for this disease (Table 1), which can probably be explained by the manner of dispersal of the disease in the field, which is not uniform, and the lesions being on the inner surface of the leaves. However, for both the traits, there was predominance of the estimates of Spearman correlation $\left(r_{s}\right)$ above 0.60 and significant, both in observations in each environment and in the overall $r_{s}$ (Table 1), indicating the predominance of a simple interaction. This supports that observed in the estimates of $r_{s}$; coincidence was high $(C=$ $80 \%$ ) for both diseases, i.e., four of the five superior lines would coincide in selection under both $\mathrm{N}$ sources.

The small effect of the interaction between lines and $\mathrm{N}$ sources for reaction to anthracnose can be seen by the high estimates of $r_{s}$ and high coincidences in selection, and upon confirming that six of the best lines in the overall classification are also among those of greatest resistance in both $\mathrm{N}$ sources (Table 3). Thus, selection could be done based on the overall mean, without loss. The lines CNFP 15208, CNFP 15188, CNFP 15193, CNFP 15194, CNFP 15207, and BRS Esteio were quite resistant, with overall mean scores ranging from 1.2 to 2.0 (Table 3). For reaction to angular leaf spot, the most resistant lines were CNFP 15171, CNFP 15177, CNFP 15174, CNFP 15178 and BRS Esplendor, with scores ranging from 3.3 to 3.9. Melo et al. (2008) consider that lines with scores greater than or equal to 3.1 should be considered as susceptible. Thus, although the previously cited lines are allocated in the group of lower scores, they still present relative susceptibility to the pathogen. This may be related to the difficulty in identifying black seeded common bean cultivars resistant to angular leaf spot (Pereira et al., 2013).

Recently, symbiotic rhizobacteria, such as those of the Rhizobium genus, have been used as bio-inoculants, as biopesticide with potential for control of diverse plant pathogens (Sridevi and Poonguzhali, 2014). The use of $R$. tropici in inoculation of common bean lines may have indirectly reduced the occurrence of anthracnose in the lines through improving atmospheric $\mathrm{N}_{2}$ fixation capacity (Ahemad and Khan, 2010) or through inducing resistance through production of defense compounds (Glick, 2012). Potentially, for angular leaf spot, balanced fertilization of $\mathrm{N}$ through urea and SNF were equally sufficient for plants to respond to the disease in a similar manner.

For all traits related to nodulation, differences were observed among the lines, environments, and $\mathrm{N}$ sources (Table 4). Variability among lines has already been reported for several of these traits (Ferreira et al., 2010; Knupp et al., 2013; Andraus et al., 2016). The influence of the type of $\mathrm{N}$ fertilization in black bean lines class has especially been reported for NN (number of nodules) and NDM (nodule dry matter) (Barros et al., 2013; Yagi et al., 2015; Brito et al., 2015). Regarding to the N source, higher NN, NDM, specific weight of nodules (SWN), and relative nodulation index (RNI) were obtained when there was inoculation with rhizobia, as expected.

The interaction between lines and $\mathrm{N}$ sources was significant for all traits (Table 4). The estimates of Spearman correlation $\left(\mathrm{r}_{\mathrm{s}}\right)$ and of coincidence in selection corroborate the existence of interaction. For all traits, all the estimates of $r_{s}$ in each environment and overall were non-significant, indicating the predominance of a complex type interaction. The 
coincidence for SWN was $20 \%$; i.e., only one line would coincide in selection in the two $\mathrm{N}$ sources. For NN, NDM, and RNI, the coincidence of $40 \%$ indicates that the two superior lines would coincide in selection. This result highlights the importance of the $\mathrm{L} \times \mathrm{S}$ interaction, and that the $\mathrm{N}$ source used during the selection process is important.

Table 4. Summary of combined analyses of variance for number of nodules per plant $\left(\mathrm{NN}-\right.$ unit.plant $\left.^{-1}\right)$, nodule dry matter $\left(\mathrm{NDM}-\mathrm{mg} \cdot \mathrm{plant}^{-1}\right)$, specific weight of nodules $\left(\mathrm{SWN}-\mathrm{mg} \cdot\right.$ nodule $\left.^{-1}\right)$, and relative nodulation index (RNI) in black beans.

\begin{tabular}{|c|c|c|c|c|c|c|c|c|c|}
\hline \multirow{2}{*}{ Source of variation } & \multirow{2}{*}{ DF $^{1}$} & \multicolumn{2}{|l|}{$\mathbf{N N}$} & \multicolumn{2}{|l|}{ NDM } & \multicolumn{2}{|l|}{ SWN } & \multicolumn{2}{|l|}{ RNI } \\
\hline & & $\mathbf{M S}^{2}$ & P-value & MS & P-value & MS & P-value & MS & P-value \\
\hline Blocks/Experiment ${ }^{*}$ & 8 & 68 & 0.124 & 67 & 0.018 & 0.3 & 0.266 & 0.17 & 0.106 \\
\hline Lines (L) & 14 & 1,533 & 0.000 & 3,133 & 0.000 & 2.6 & 0.000 & 4.21 & 0.000 \\
\hline Environments (E) & 1 & 7,776 & 0.000 & 7,153 & 0.000 & 23.0 & 0.000 & 18.13 & 0.000 \\
\hline N Sources (S) & 1 & 46,994 & 0.000 & 221,135 & 0.000 & 43.7 & 0.000 & 175.6 & 0.000 \\
\hline$L \times E$ & 14 & 2,097 & 0.000 & 4,894 & 0.000 & 4.6 & 0.000 & 5.75 & 0.000 \\
\hline $\mathrm{L} \times \mathrm{S}$ & 14 & 1,311 & 0.000 & 2,144 & 0.000 & 4.3 & 0.000 & 2.60 & 0.000 \\
\hline$E \times S$ & 1 & 3,311 & 0.000 & 16,183 & 0.000 & 66.7 & 0.000 & 59.22 & 0.000 \\
\hline $\mathrm{L} \times \mathrm{E} \times \mathrm{S}$ & 14 & 1,917 & 0.000 & 4,580 & 0.000 & 4.8 & 0.000 & 5.11 & 0.000 \\
\hline Residue & 112 & 42 & - & 28 & - & 0.2 & - & 0.10 & - \\
\hline Total & 179 & - & & - & & - & & - & \\
\hline $\mathrm{Mean}^{3}$ & & 25.9 & & 52.3 & & 2.12 & & 2.57 & \\
\hline$C^{4}(\%)$ & & 40 & & 40 & & 20 & & 40 & \\
\hline $\mathrm{CV}^{5}(\%)$ & & 25.0 & & 10.1 & & 21.3 & & 12.2 & \\
\hline $\mathrm{r}_{\mathrm{s}}{ }^{6}$ & & $0.15^{\text {ns }}$ & & $0.33^{\text {ns }}$ & & $-0.18^{\mathrm{ns}}$ & & $0.35^{\mathrm{ns}}$ & \\
\hline
\end{tabular}

${ }^{1}$ Degrees of freedom; ${ }^{2}$ Mean square; ${ }^{3}$ Overall mean; ${ }^{4}$ Coincidence $(\%)$ of selection of the $30 \%$ (six) best common bean lines; ${ }^{5}$ Coefficient of variation; 'Spearman correlation: " non-significant $(\mathrm{P}>0.05)$ by the Student $\mathrm{t}$ test. "Experiment: combination of location/growing season/year/N source.

For NN, the performance of the cultivar IPR Uirapuru, with a mean of 98.4 nodules plant $^{-1}$, stood out under inoculation (Table 5), similar to what was reported by Oliveira and Sbardelotto (2011). BRS Esplendor, BRS Campeiro, and BRS Esteio presented few nodules, regardless of the N source. Andraus et al. (2016) also observed that the cultivar BRS Campeiro has low nodulation, even with inoculation of rhizobia.

The lines CNFP 15198 and CNFP 15177 had the highest mean values of NDM under SNF (132.7 and 130.3 mg.plant ${ }^{-1}$, respectively) (Table 5). In spite of not being in the first group of mean values, the cultivars IPR Uirapuru and BRS Campeiro had expressive NDM under SNF. In contrast, BRS Esteio and BRS Esplendor had relatively low NDM.

Nodulation of the common bean lines was observed even when there was only mineral $\mathrm{N}$ fertilization, suggesting the presence of native bacteria strains in the locations of the experiments. Nodulation in the absence of inoculation in black bean lines has been reported (Barros et al., 2013; Fonseca et al., 2013; Brito et al., 2015). Nevertheless, NN and MSN in this condition were lower, as expected (Brito et al., 2015).

In relation to SWN, the cultivar BRS Campeiro had the highest mean value under SNF (4.59 mg.nodule ${ }^{-1}$ ) (Table 5). The size of the nodule, though not often used as a criterion of nodulation, is important because there is correlation between nodule weight and the amount of $\mathrm{N}$ accumulated in seed legumes. Thus, there must be several nodules, but of appropriate size, with greater relative efficiency (Hansen et al., 1993).

As various traits of nodulation are important, the relative nodulation index is more suitable for carrying out selection of superior genotypes. The cultivar BRS Campeiro and the line CNFP 15177 had the highest RNIs under SNF (Table 5). Although the cultivar BRS 
Campeiro did not stand out in regard to NN, it had notable NDM and the highest SWN, which are two traits with greater weight in the selection index. In general, the lines superior for nodulation traits do not have the highest seed yields (Table 2).

Table 5. Number of nodules (NN - unit.plant $\left.{ }^{-1}\right)$, nodule dry matter $\left(\mathrm{NDM}-\right.$ mg.plant $\left.^{-1}\right)$, specific weight of nodules (SWN - mg.nodule ${ }^{-1}$ ), and relative nodulation index (RNI) of black seeded common bean lines under nitrogen fertilization (Nitro) and inoculation with rhizobia (Inoc) evaluated in Santo Antônio de Goiás, GO, Brazil. Mean values of two growing seasons: 2013 rainy season and 2014 winter season.

\begin{tabular}{|c|c|c|c|c|c|c|c|c|c|c|c|c|c|c|c|c|}
\hline \multirow{2}{*}{ Line } & \multicolumn{4}{|l|}{$\mathbf{N N}$} & \multicolumn{4}{|l|}{ NDM } & \multicolumn{4}{|l|}{ SWN } & \multicolumn{4}{|l|}{ RNI } \\
\hline & Nitro & & Inoc & & Nitro & & Inoc & & Nitro & & Inoc & & Nitro & & Inoc & \\
\hline BRS FP403 & 11.1 & $\mathrm{Bb}$ & 56.7 & $\mathrm{Ba}$ & 28.2 & $\mathrm{Bb}$ & 112.2 & $\mathrm{Ba}$ & 2.012 & $\mathrm{Bb}$ & 2.774 & $\mathrm{Ba}$ & 2.04 & $\mathrm{Cb}$ & 4.13 & $\mathrm{Ca}$ \\
\hline BRS Esteio & 11.3 & $\mathrm{Ba}$ & 15.0 & $\mathrm{Fa}$ & 17.5 & $\mathrm{Cb}$ & 45.3 & $\mathrm{Ha}$ & 1.137 & $\mathrm{Cb}$ & 2.941 & $\mathrm{Ba}$ & 1.21 & $\mathrm{Db}$ & 3.02 & $\mathrm{Fa}$ \\
\hline BRS Esplendor & 7.7 & $\mathrm{Bb}$ & 36.7 & $\mathrm{Da}$ & 5.8 & $\mathrm{Db}$ & 77.6 & $\mathrm{Ea}$ & 0.568 & $\mathrm{Db}$ & 2.323 & $\mathrm{Ca}$ & 0.58 & $\mathrm{~Eb}$ & 3.15 & $\mathrm{Ea}$ \\
\hline BRS Campeiro & 10.0 & $\mathrm{Bb}$ & 27.3 & $\mathrm{Ea}$ & 13.3 & $\mathrm{Cb}$ & 112.3 & $\mathrm{Ba}$ & 1.089 & $\mathrm{Cb}$ & 4.590 & $\mathrm{Aa}$ & 1.11 & $\mathrm{Db}$ & 5.33 & $\mathrm{Aa}$ \\
\hline CNFP 15171 & 6.2 & $\mathrm{Bb}$ & 24.6 & $\mathrm{Ea}$ & 5.3 & $\mathrm{Db}$ & 80.0 & $\mathrm{Ea}$ & 0.824 & $\mathrm{Db}$ & 2.593 & $\mathrm{Ba}$ & 0.76 & $\mathrm{~Eb}$ & 3.31 & $\mathrm{Ea}$ \\
\hline IPR Uirapuru & 6.0 & $\mathrm{Bb}$ & 98.4 & $\mathrm{Aa}$ & 31.0 & $\mathrm{Bb}$ & 107.2 & $\mathrm{Ba}$ & 3.209 & $\mathrm{Aa}$ & 1.952 & $\mathrm{Db}$ & 2.97 & $\mathrm{Ab}$ & 3.73 & $\mathrm{Da}$ \\
\hline CNFP 15178 & 5.1 & $\mathrm{Bb}$ & 25.6 & $\mathrm{Ea}$ & 6.6 & $\mathrm{Db}$ & 52.3 & $\mathrm{Ga}$ & 1.256 & $\mathrm{Cb}$ & 2.341 & $\mathrm{Ca}$ & 1.11 & $\mathrm{Db}$ & 2.73 & $\mathrm{Fa}$ \\
\hline CNFP 15174 & 6.8 & $\mathrm{Bb}$ & 29.8 & $\mathrm{Ea}$ & 10.1 & $\mathrm{Db}$ & 66.9 & $\mathrm{Fa}$ & 1.265 & $\mathrm{Cb}$ & 2.554 & $\mathrm{Ba}$ & 1.17 & $\mathrm{Db}$ & 3.13 & $\mathrm{Ea}$ \\
\hline CNFP 15194 & 5.3 & $\mathrm{Bb}$ & 25.7 & $\mathrm{Ea}$ & 10.1 & $\mathrm{Db}$ & 88.9 & $\mathrm{Da}$ & 1.504 & $\mathrm{Cb}$ & 3.054 & $\mathrm{Ba}$ & 1.35 & $\mathrm{Db}$ & 3.80 & $\mathrm{Da}$ \\
\hline CNFP 15193 & 7.9 & $\mathrm{Bb}$ & 46.5 & $\mathrm{Ca}$ & 6.5 & $\mathrm{Db}$ & 67.7 & $\mathrm{Fa}$ & 0.924 & $\mathrm{Db}$ & 1.799 & $\mathrm{Da}$ & 0.87 & $\mathrm{~Eb}$ & 2.68 & $\mathrm{Fa}$ \\
\hline CNFP 15207 & 29.2 & $\mathrm{Ab}$ & 61.0 & $\mathrm{Ba}$ & 41.2 & $\mathrm{Ab}$ & 96.7 & $\mathrm{Ca}$ & 2.116 & $\mathrm{Ba}$ & 1.898 & $\mathrm{Da}$ & 2.43 & $\mathrm{Bb}$ & 3.27 & $\mathrm{Ea}$ \\
\hline CNFP 15198 & 5.9 & $\mathrm{Bb}$ & 57.1 & $\mathrm{Ba}$ & 13.1 & $\mathrm{Cb}$ & 132.7 & $\mathrm{Aa}$ & 2.202 & $\mathrm{Ba}$ & 2.412 & $\mathrm{Ca}$ & 1.94 & $\mathrm{Cb}$ & 4.14 & $\mathrm{Ca}$ \\
\hline CNFP 15208 & 13.7 & $\mathrm{Bb}$ & 38.7 & $\mathrm{Da}$ & 40.9 & $\mathrm{Ab}$ & 72.6 & $\mathrm{Fa}$ & 2.485 & $\mathrm{Ba}$ & 2.077 & $\mathrm{Da}$ & 2.60 & $\mathrm{Ba}$ & 2.90 & $\mathrm{Fa}$ \\
\hline CNFP 15177 & 6.8 & $\mathrm{Bb}$ & 52.0 & $\mathrm{Ca}$ & 17.2 & $\mathrm{Cb}$ & 130.3 & $\mathrm{Aa}$ & 2.974 & $\mathrm{Aa}$ & 2.948 & $\mathrm{Ba}$ & 2.60 & $\mathrm{Bb}$ & 4.48 & $\mathrm{Ba}$ \\
\hline CNFP 15188 & 12.6 & $\mathrm{Bb}$ & 35.1 & $\mathrm{Da}$ & 11.5 & $\mathrm{Cb}$ & 67.3 & $\mathrm{Fa}$ & 0.880 & $\mathrm{Db}$ & 2.967 & $\mathrm{Ba}$ & 0.94 & $\mathrm{~Eb}$ & 3.50 & $\mathrm{Ea}$ \\
\hline Mean & 9.7 & $\mathrm{~b}$ & 42.0 & $a$ & 17.2 & $\mathrm{~b}$ & 87.3 & $\mathrm{a}$ & 1.630 & $\mathrm{~b}$ & 2.615 & $\mathrm{a}$ & 1.58 & $\mathrm{a}$ & 3.55 & $\mathrm{a}$ \\
\hline
\end{tabular}

Mean values followed by the same lowercase letters in the table line and uppercase letters in the table column (Scott-Knott method, $\alpha=$ $10 \%$ ) do not differ statistically.

Likewise, neither of the two highest yielding cultivars under SNF (BRS Esteio and BRS FP403) had a high RNI index. Thus, these results suggest the need to develop common bean breeding populations that can combine high seed yield and high nodulation ability, crossing superior parents for these traits identified by the present study. The objective is to obtain lines that combine high yield with nodulation efficiency and that can thus maintain yields under conditions of $\mathrm{N}$ supply exclusively through SNF that are similar to yields obtained in a system with $\mathrm{N}$ fertilization.

Using the RNI selection index as a criterion, the cultivar BRS Campeiro and the line CNFP 15177 had the best overall performance in regard to nodulation traits. Although they were not the highest yielding (Table 2), their mean values were higher or very near to the mean value under inoculation $\left(2,396 \mathrm{~kg} \cdot \mathrm{ha}^{-1}\right)$. Neither of the two highest yielding cultivars under SNF (BRS Esteio and BRS FP403) was superior for evaluation of nodulation. However, the cultivar BRS FP403 shown good results for number of nodules, specific weight of nodules, and relative nodulation index, which was higher than 4.0. The results show that selection of superior common bean lines for the nodulation traits is not associated with the best yields, but rather with the lowest reduction in seed yield with the change in N source (greater RYINs).

\section{CONCLUSIONS}

There was an effect of $\mathrm{N}$ source on seed yield of black common bean lines, with better performance of the lines under $\mathrm{N}$ fertilization, when consideroing 100 -seed weight 
and reaction to anthracnose. The interaction between lines and $\mathrm{N}$ sources for seed yield, sieve yield, and reaction to anthracnose did not influence selection of the best performing lines. The black seeded cultivars BRS FP403 and BRS Esteio are recommended for growing using $\mathrm{N}$ fertilization or with the use of inoculation with rhizobia because they have high seed yield and wide adaptability and stability indepent of $\mathrm{N}$ source. There is genetic variability among the black beans elite lines for traits related to nodulation. The cultivar BRS Campeiro and the line CNFP 15177 have high nodulation. Although it was possible to select lines with high seed yield under inoculation with rhizobia, the lines that have the highest yields on this condition are not those that have the highest degree of nodulation. To combine high seed yield and high nodulation, it is would be useful to conduct a breeding program exclusively under inoculation, making crosses among the lines with high nodulation (e.g. BRS Campeiro and CNFP 15177) and the highest yielding lines (e.g. BRS FP403 and BRS Esteio).

\section{ACKNOWLEDGMENTS}

The authors thank Embrapa Arroz e Feijão for funding this study; CNPq (Brazilian Council for Scientific and Technological Development) for granting scholarships of productivity in technological development and innovative extension to T.L.P.O. Souza, L.C. Melo, P.G.S. Melo, and H.S. Pereira, and a research productivity scholarship to E.P.B. Ferreira; the Fundação de Amparo à Pesquisa do Estado de Goiás (FAPEG) for granting a Ph.D. scholarship to P.A.S. Dias; and Embrapa Produtos e Mercado (Ponta Grossa and Brasília agencies), the Universidade Federal de Goiás, the Empresa Mato-grossense de Pesquisa, Assistência e Extensão Rural, and Embrapa Tabuleiros Costeiros for support in carrying out the field experiments.

\section{CONFLICTS OF INTEREST}

The authors declare no conflict of interest.

\section{REFERENCES}

Ahemad M and Khan MS (2010). Comparative toxicity of selected insecticides to pea plants and growth promotion in response to insecticide-tolerant and plant growth promoting Rhizobium leguminosarum. Crop Prot. 29: 325-329.

Andraus MP, Cardoso AA and Ferreira EPB (2016). Differences in nodulation and grain yield on common bean cultivars with different growth cycles. Commun. Soil Sci. Plant Anal. 47: 1148-1161.

Barros RLN, Oliveira LB, Magalhães WB, Médici LO, et al. (2013). Interação entre inoculação com rizóbio e adubação nitrogenada de plantio na produtividade do feijoeiro nas épocas da seca e das águas. Semin. Ciênc. Agrár. 34: 14431450 .

Brito LF, Pacheco RS, Souza Filho BF, Ferreira EPB, et al. (2015). Response of Common Bean to Rhizobium Inoculation and Supplemental Mineral Nitrogen in Two Brazilian Biomes. Rev. Bras. Ciênc. Solo. 39: 981-992.

Brito OR, Otsubo AA, Mercante FM and Otsubo VHN (2008). Evaluation of the Carioca and black beans group lines inoculated with Rhizobium tropici strains. Annu. Rep. Bean Improv. Coop. 51: 254-255.

Brito OR, Otsubo AA, Mercante FM, Hayashi NLM, et al. (2010). Nitrogen fertilization and inoculation with Rhizobium tropici in black bean. Annu. Rep. Bean Improv. Coop. 53: 172.

Cardoso JD, Gomes DF, Goes KCGP, Fonseca Junior NS, et al. (2009). Relationship between total nodulation and nodulation at the root crown of peanut, soybean and common bean plants. Soil Biol. Biochem. 41: 1760-1763.

Cochran WG (1954). The combination of estimates from different experiments. Biometrics. 10: 101-129.

Devi MJ, Sinclair TR, Beebe SE and Rao IM (2013). Comparison of common bean (Phaseolus vulgaris L.) genotypes for nitrogen fixation tolerance to soil drying. Plant Soil. 364: 29-37. 
Dwivedi SL, Sahrawat KL, Upadhyaya HD, Mengoni A, et al. (2015). Advances in host plant and Rhizobium genomics to enhance symbiotic nitrogen fixation in grain legumes. Adv. Agron. 129: 1-116.

Fageria NK, Melo LC and Oliveira J (2013). Nitrogen use efficiency in dry bean genotypes. J. Plant Nutr. 36: 21792190.

Fageria NK, Ferreira EPB, Melo LC and Knupp AM (2014). Genotypic differences in dry bean yield and yield components as influenced by nitrogen fertilization and rhizobia. Commun. Soil Sci. Plant Anal. 45: 1583-1604.

Fageria NK, Melo LC and Carvalho MCS (2015). Influence of nitrogen on growth, yield, and yield components and nitrogen uptake and use efficiency in dry bean genotypes. Commun. Soil Sci. Plant Anal. 46: 2395-2410.

FAO (2014). FaoStat. Available at [http://www.fao.org/faostat/en/\#data/QC]. Accessed 05 April 2020.

Faria LC, Melo PGS, Pereira HS and Melo LC (2017). Genetic gain in common bean with black grain by indirect estimation methods. Crop Sci. 57: 1308-1314.

Faria LC, Melo PGS, Pereira HS, Wendland A, et al. (2014). Genetic progress during 22 years of black bean improvement. Euphytica. 199: 261-272.

Farid M, Earl HJ and Navabi A (2016). Yield stability of dry bean genotypes across nitrogen fixation-dependent and fertilizer-dependent management systems. Crop Sci. 56: 173-182.

Farid M, Earl HJ, Pauls KP and Navabi A (2017). Response to selection for improved nitrogen fixation in common bean (Phaseolus vulgaris L.). Euphytica. 213: 99-111.

Farid M and Navabi A (2015). $\mathrm{N}_{2}$ fixation ability of different dry bean genotypes. Can. J. Plant Sci. 95: 1243-1257.

Feijão (2018). Dados conjunturais do feijão (área, produção e rendimento) no Brasil de 1985 a 2018. Available at [http://www.cnpaf.embrapa.br/socioeconomia/index.htm]. Accessed 05 April 2020.

Ferreira EPB, Barbosa LHA, Knupp AM, Mata WM, et al. (2010). Identification of high nodulation efficiency among wild genotypes of common beans. Annu. Rep. Bean Improv. Coop. 53: 170-171.

Fonseca GG, Oliveira DP, Soares BL, Ferreira PAA, et al. (2013). Resposta de cultivares de feijoeiro-comum à inoculação das sementes com duas estirpes de rizóbio. Biosci. J. 29:1778-1787.

Glick BR (2012). Plant growth-promoting bacteria: mechanisms and applications. Scientifica. 2012: 1-15.

Hansen AP, Yoneyama T, Kouch H and Martin P (1993). Respiration and nitrogen fixation of hydroponically cultured Phaseolus vulgaris L. cv. OAC Rico and a supernodulating mutant. Planta. 189: 538-545.

Heilig JA, Wright EM and Kelly JD (2017). Symbiotic nitrogen fixation of black and navy bean under organic production systems. Agron J. 109: 2223-2230.

Huang HC, Erickson RS and Hsieh TF (2007). Control of bacterial wilt of bean (Curtobacterium flaccumfaciens pv. flaccumfaciens) by seed treatment with Rhizobium leguminosarum. Crop Prot. 26: 1055-1061.

Hungria M and Vargas MAT (2000). Environmental factors affecting $\mathrm{N}_{2}$ fixation in grain legumes in the tropics, with an emphasis on Brazil. Field Crops Res. 65: 151-164.

IBGE (2019). $\quad$ Censo Agropecuário $2017 . \quad$ Available [https://biblioteca.ibge.gov.br/visualizacao/periodicos/3096/agro_2017_resultados_definitivos.pdf ]. Accessed 05 April 2020.

Kamfwa K, Cichy KA and Kelly JD (2015). Genome-wide association analysis of symbiotic nitrogen fixation in common bean. Theor Appl Genet. 128: 1999-2017.

Knupp AM, Ferreira EPB, Wendland A, Melo LC, et al. (2013). Assessment of Mesoamerican and Andean common bean genotypes for high-nodulation efficiency. Annu. Rep. Bean Improv. Coop. 56: 79-80.

Melo LC (2009). Procedimentos para condução de experimentos de Valor de Cultivo e Uso em Feijoeiro Comum. Embrapa [Documentos, 239]. Embrapa, Santo Antônio de Goiás, GO.

Melo CLP, Ragagnin VA, Arruda KMA, Barros EG, et al. (2008). Caracterização fenotípica e molecular de genitores de feijão tipo carioca quanto à resistência a patógenos. Pesqui. Agropecu. Bras. 43: 495-504.

Moreira LP, Oliveira APS and Ferreira EPB (2017). Nodulation, contribution of symbiotic N2 fixation, and productivity of the common bean (Phaseolus vulgaris L.) inoculated with rhizobia isolates. Aust. J. Crop Sci.11: 644-651.

Nunes JAR, Ramalho MAP and Abreu AFB (2005). Graphical method in studies of adaptability and stability of cultivars. Annu. Rep. Bean Improv. Coop. 48: 182-183.

Oliveira JP, Galli-Terasawa LV, Enke CG, Cordeiro VK, et al. (2011). Genetic diversity of rhizobia in a Brazilian oxisol nodulating Mesoamerican and Andean genotypes of common bean (Phaseolus vulgaris L.). World J. Microbiol. Biotechnol. 27: 643-650.

Oliveira R C and Sbardelotto JM (2011). Nodulação em diferentes variedades de feijão inoculadas com Rhizobium tropici. Cultiv. Saber. 4: 46-52.

Pelegrin R, Mercante FM, Miyuki I, Otsubo N, et al. (2009). Resposta da cultura do feijoeiro à adubação nitrogenada e à inoculação com rizóbio. Rev. Bras. Ciênc. Solo. 33: 219-226.

Pereira HS, Almeida VM, Melo LC, Wendland A, et al. (2012). Influência do ambiente em cultivares de feijoeirocomum em cerrado com baixa altitude. Bragantia. 71: 165-172.

Pereira HS, Faria LC, Wendland A, Costa JGC, et al. (2018). Genotype by environment interaction for disease resistance and other important agronomic traits supporting the indication of common bean cultivars. Euphytica. 214: 1 . 
Pereira HS, Melo LC, Faria LC, Wendland A, et al. (2013). BRS Esteio - Common bean cultivar with black grain, high yield potential and moderate resistance to anthracnose. Crop Breed. Appl. Biotechnol. 13: 373-376.

Pereira HS, Melo LC, Faria LC, Ferreira EPB, et al. (2015). Common bean elite lines cultivated under nitrogen fertilization and inoculation with Rhizobium tropici. Ciênc. Rural. 42: 2168-2173.

Pimentel-Gomes F (2009). Curso de estatística experimental. 15 ed. Esalq. Piracicaba.

Sridevi MLS and Poonguzhali TV (2014). Antagonistic effect of Rhizobium leguminosarum, Pseudomonas fluorescens and Bacillus subtilis in cowpea [Vigna uniguiculata (L.) Walp.] under in vitro condition. Int. J. Adv. Res. 2: 497500 .

Torga PP, Melo PGS, Pereira HS, Faria LC, et al. (2016). Genetic potential of black bean genotypes with predictable behaviors in multienvironment trials. Genet. Mol. Res. 15: gmr15049029.

Torga PP, Melo PGS, Pereira HS, Faria LC, et al. (2013). Interaction of common beans cultivars of the black group with years, locations and sowing seasons. Euphytica. 189: 239-248.

Yagi R, Andrade DS, Waureck A and Gomes JC (2015). Nodulations and grain yields of common bean in response to nitrogen fertilization or seed inoculation with Rhizobium freirei. Rev. Bras. Ciênc. Solo. 39: 1661-1670.

Zimmermann FJP (2004). Estatística aplicada à pesquisa agrícola. Embrapa Arroz e Feijão, Santo Antônio de Goiás. 